\title{
新ファイバーラインの操業経験*
}

\author{
北越製紙株式会社 新潟工場パルプ課 鈴 見 竜 一
}

\section{The Experience of New Pulping Plant Operation}

\section{Ryuuichi Suzumi}

Chemical Pulping Department, Niigata Mill, Hokuetsu Paper Mills Ltd.

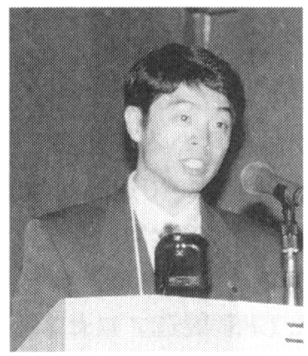

Hokuetsu Niigata Mill started up the new coated paper machine (PM 8) in July 1998. To meet the needs of increasing pulp production the new pulping plant (E line) started up earlier than PM 8. This plant introduced ECF bleaching with D 0-Eo-DnD sequence.

This report describes the outline and operating experiences of this pulping plant.

分類 $: \mathrm{K}_{3}$ 酸素漂白, $\mathrm{K}_{7}$ 二酸化塩素漂白

\section{1.はじめに}

北越製紙新潟工場は，日産 500 トンのエスコ連釜系 列 (C 系) と日産 700 トンのカミヤ連釜系列 (D 系) の 2 つのパルププラントを有していたが、1998年 7 月のオンコーターマシン 8 号抄紙機の運転に先駆け, 同年 2 月に日産 1,200 トンの新プラント（E系）を稼 動させた。そして老朽化し, 品質や効率の低いC系 を予備ラインとし, D 系 $\mathrm{E}$ 系合わせて 1,900 トンの パルプ製造能力を持つ工場へと生まれ変わった。

新プラントは, 地域との共生を主眼とし, 環境負荷 へ最大の配慮をした結果, 世界の主流となりつつある ECF (Elemental Chlorine Free) 漂白, いわゆる無塩 素漂白を, 大規模プラントでしかもパルプ〜紙の一貫 工場としては日本で初めて採用した。

なお ECF 漂白による漂白コストアップを最小限に とどめるため, 蒸解釜は低カッパー価でも高いパルプ 品質を維持できるクヴァナ社の ITC（Isothermal Cooking）蒸解釜を既に採用していた。今回は蒸解釜

\footnotetext{
*平成 11 年度年次大会講演 (講演 No. B 2)
}

以降の $\mathrm{E}$ 系未晒・组ファイバーラインの設備概要, 操業経験を中心に報告する。

\section{2. 設 備 概 要}

$2.1 \mathrm{E}$ 系フロー

フローの構築にあたっては, 次の点をコンセプトに 掲げた。

・ECF 漂白による環境負荷の低減

・省エネルギー, 省用水

・パルプの高品質化

・適切なハードの適切な工程への採用

・操業性, 安定性の良いソフトの構築

新ファイバーライン $\mathrm{E}$ 系のフローを図1に示す。 蒸解釜からブロータンクまでの設備はクヴァナ社に発 注し, 1997 年 10 月に運転を開始した。それ以降の未 晒・晒設備は住重アールストローム社に発注し ECF 漂白ラインとして 1998 年 2 月に運転に入った。ファ イバーラインの主な機器はアールストローム製である が，酸素漂白段前の洗浄機（BSW）と未晒最終段の 洗浄機（POW-2）は各キャリオーバーを最少化させ る目的でスンズ社の置換プレスを採用した。 


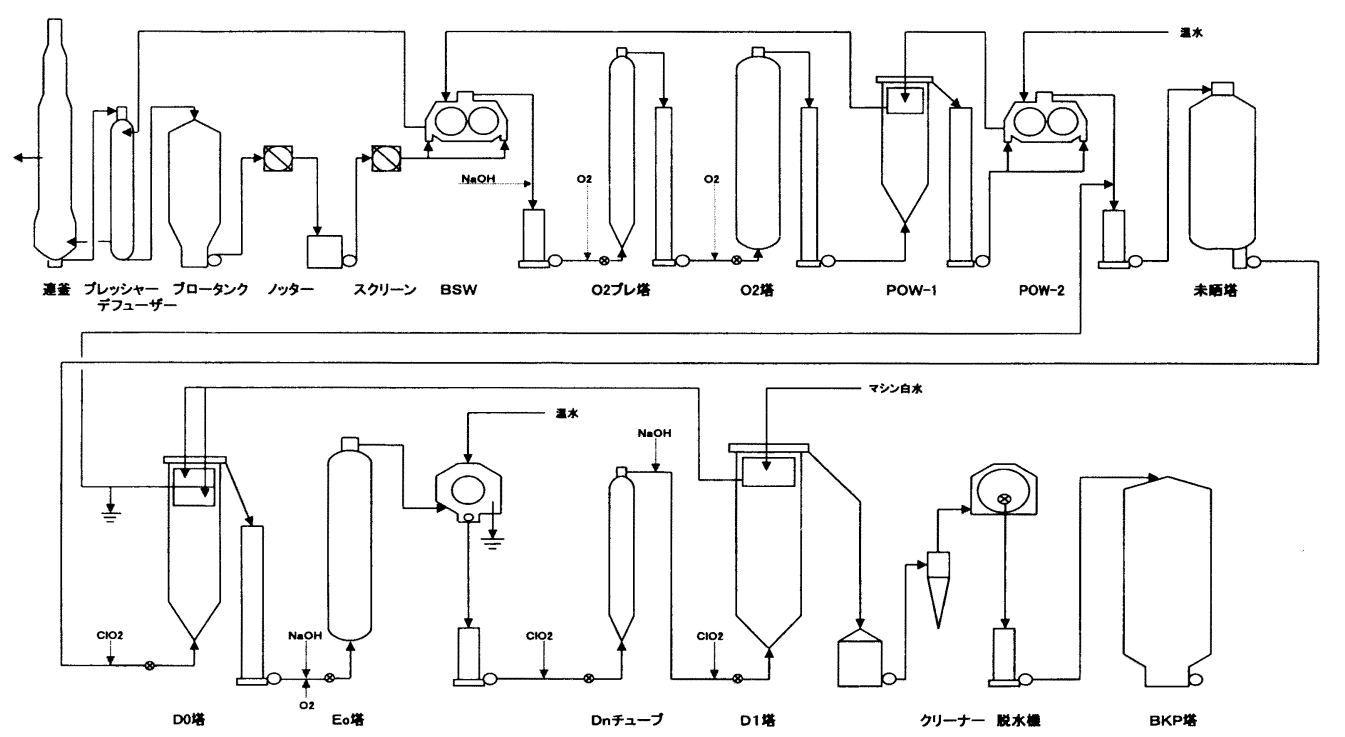

図 1 北越製紙新潟工場 $\mathrm{E}$ 系未哂・哂フロー

漂白シーケンスは未晒の 2 段酸素漂白の後, $\mathrm{D}^{-} \mathrm{EO}^{-}$ $\mathrm{DnD}$ の 3.5 段漂白であり, Eo 段は過酸化水素を用い た Eop 段へも対応可能である。また晒工程の洗浄機 は省スペースを図る為 DW（デフューザー）を基本と したが，アルカリ段は後段薬品の減少を図る目的と, スケールトラブルが発生した場合の薬品洗浄の行い易 さからアールストロームの DD ウォシャー（Drum Displacer）を採用した。未晒・晒設備の主な仕様を 表 1 に示す。

\section{2 プラントメーカー保証值}

新ファイバーラインの設計基準として表 2 の項目を プラントメーカー保証値に掲げた。

この中で(2)の脱リグニン率は, 設計段階よりも低い入 ロカッパー価で操業を行っているため, 操業值は保証 值より若干劣っている。

(4)の漂白薬品の原単位に関しては, 当社は約 10 種 類にものほる異なるチップから，5～6 種類をブレン ドして使っており, その時々で蒸解性, 漂白性も異な るため, 実機と同一の未晒パルプを使ったラボ漂白試 験を行い, ラボでの漂白薬品原単位とその時の実機で の原単位を比較評価することとした。

\section{3. 操業状況}

\section{1 操業全般の状況}

E 系ファイバーラインの初期トラブルとしては,

・油圧機器, 配管の洩れ, 破損

・希釈，原料配管の振動による亀裂

などが発生し，配管ルートの見直しや，配管サポート
を強化する事で解決した。

また操業上ではインターロックで停止した時に, 臭 気ガスラインヘパルプが逆流し, 配管を詰らせる現象 が起こったが，これは反応塔圧力をコントロールする 調節弁のシーケンスを変更することで防止できた。

\section{2 末唒工程の状況}

未晒の操業状況を表 3 に示す。スリットスクリーン の未酔工程での使用は初めての試みであったが, 結束 緎維や異物の分離効果は予想以上であった。しかしそ の反面バスケットの寿命が短く，半年で交換せざる得 なくなった。現在は耐摩耗を強化したバスケットを使 用し延命対策を図っている。またチップハンドリング 設備を含めた各トラップの排出頻度を増やすことで原 料中の金属異物と砂利，砂の除去に努めている。

$\mathrm{E}$ 系と $\mathrm{D}$ 系の BSW 出口固形分量と酸素段入口固形 分量の比較を図 2 に示す。酸素段前のプレスは少ない 段数での効率的な洗浄を目的としており, フィルター 型洗浄機を 2 台使用している D 系と比較しても, E 系での BSW 出口固形分量は, D 系の半分以下である。 酸素段入口では $\mathrm{O}_{2}$ 塔への設定供給濃度まで希釈する 必要があり, 固形分量が増加してしまうが，そこでも $\mathrm{E}$ 系は $\mathrm{D}$ 系の 7 割強である。

酸素段での脱リグニン率は約 $45 \%$ であり, 2 段の内 訳は 1 塔目で約 8 割, 2 塔目で残り 2 割の反応となっ ている（図 3)。先に述べたように薬品原単位や排水 負荷低減などの面から，ブローカッパー価を計画より 下げて操業しており，保証值には未達である。しかし ブローカッパー価が上昇した時は, 脱リグニン率も上 


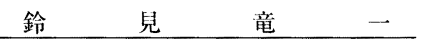

表 $1 \mathrm{E}$ 末晒・晒設備仕様

\begin{tabular}{|c|c|c|}
\hline 工程 & メーカー & 型 \\
\hline 未晒精選 & アールストローム & $\begin{array}{l}1 \text { 次ノッター }: \mathrm{C}-8(8 \mathrm{~mm} \phi) \\
2 \text { 次ノッター: } \mathrm{KW}-8(8 \mathrm{~mm} \phi) \\
1 \text { 次スクリーン }: \mathrm{F}-5(0.22 \mathrm{~mm} \text { スリット }) \\
2 \text { 次スクリーン }: \mathrm{F}-3(0.25 \mathrm{~mm} \text { スリット }) \\
3 \text { 次スクリーン }: \mathrm{F}-2(0.25 \mathrm{~mm} \text { スリット })\end{array}$ \\
\hline BSW & スンズ & DPA-1555 \\
\hline 酸素段 & アールストローム & $\begin{array}{l}\mathrm{O}_{2} \text { プレ塔 : } 157 \mathrm{~m}^{3} \\
\mathrm{O}_{2} \text { 塔 : } 315 \mathrm{~m}^{3} \\
\text { ミキサー : アールミックス AM 30-25 } 2 \text { 台 } \\
\text { ディスチャージャー: } 40-\mathrm{P} 2-14 \mathrm{H} 2 \text { 台 } \\
\text { ディストリビューター : 40-P 2-14 H }\end{array}$ \\
\hline POW-1 & アールストローム & 1 段 DW：4 アーム，8リング \\
\hline POW-2 & スンズ & $\mathrm{DPB}-1255$ \\
\hline DO 段 & アールストローム & $\begin{array}{l}\text { DO 塔: } 597 \mathrm{~m}^{3} \\
2 \text { 段 DW : } 3 \text { アーム, } 5 \text { リング } \\
\text { ミキサー : アールミックス AM 25-20 }\end{array}$ \\
\hline Eo 段 & アールストローム & $\begin{array}{l}\text { Eo 塔: } 574 \mathrm{~m}^{3} \\
\text { 洗浄機：DD } 4040.1 .5 \mathrm{MCV} \\
\text { ミキサー : アールミックス AM 25-20 } \\
\text { ディスチャージャー : 40-P 2-14 H } \\
\text { ディストリビューター: } 40-\mathrm{P} 2-14 \mathrm{H}\end{array}$ \\
\hline Dn 段 & アールストローム & $\begin{array}{l}\text { Dn チューブ : } 60 \mathrm{~m}^{3} \\
\text { ミキサー : アールミックス AM 25-20 } \\
\text { ディスチャージャー : 40-P 2-14 H }\end{array}$ \\
\hline D 1 段 & アールストローム & $\begin{array}{l}\mathrm{D} 1 \text { 塔: } 1,681 \mathrm{~m}^{3} \\
1 \text { 段 DW }: 4 \text { アーム, } 7 \text { リング } \\
\text { ミキサー：アールミックス AM 25-20 }\end{array}$ \\
\hline クリーナー & NOSS & $\begin{array}{l}1 \text { 次 } 3 \text { 次 : AL } 80 \\
4 \text { 次 } ~ 6 \text { 次 }: A L ~ 80 A\end{array}$ \\
\hline 脱水機 & 丸石 & センターディスクフィルター \\
\hline
\end{tabular}

表 2 プラントメーカー保証項目

\begin{tabular}{l|l}
\hline (1)生産量 & $1,200 \mathrm{LBKP} \cdot \mathrm{ADt} / \mathrm{D}$ \\
\hline (2)酸素脱リグニン率 & $\begin{array}{l}47.5 \% \text { 以上 } \\
\text { (条件: 酸素段入口 Kappa 価 } 17 \text { 以上) }\end{array}$ \\
\hline (3)COD キャリオーバー & $5 \mathrm{~kg} / \mathrm{ADt}$ 以下 \\
\hline (4)薬品消費量 (目標值) & 同一パルプを用いたラボ漂白実験值の $105 \%$ 以下 \\
\hline
\end{tabular}


表 3 末晒操業デー夕

\begin{tabular}{|c|c|c|}
\hline 工程 & パルプ濃度 & 諸データ \\
\hline 未晒精選 & $\begin{array}{l}\text { ノッター入に： } \\
4.5 \% \\
\text { スクリーン入い： } \\
3.7 \%\end{array}$ & \\
\hline $\begin{array}{l}\text { BSW } \\
\text { (DPA) }\end{array}$ & $\begin{array}{l}\text { 入曰: } 3.7 \% \\
\text { 出口: } 34 \%\end{array}$ & \\
\hline 酸素段 & 人1 $1: 12 \%$ & 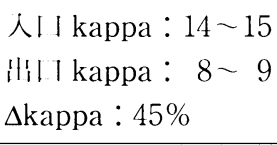 \\
\hline $\begin{array}{l}\mathrm{POW}-1 \\
(\mathrm{DW})\end{array}$ & $\begin{array}{l}\text { 入口: } 11 \% \\
\text { 出口: } 11 \%\end{array}$ & DR $: 0.8 \sim 0.9$ \\
\hline $\begin{array}{l}\mathrm{POW}-2 \\
(\mathrm{DPB})\end{array}$ & $\begin{array}{l}\text { 人に: } 6.5 \% \\
\text { 出に: } 34 \%\end{array}$ & $\begin{array}{l}\mathrm{COD} \text { キャリオーバ } \\
\text { ー : } 4.5 \mathrm{~kg} / \mathrm{ADt}\end{array}$ \\
\hline
\end{tabular}

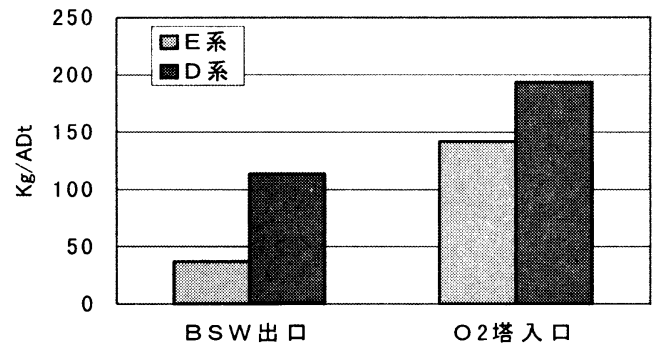

図 2 E 系と D 系の全湖形分啚比較

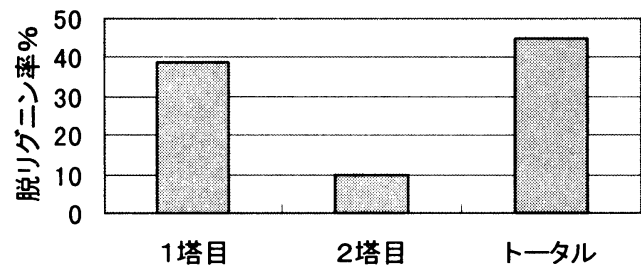

図 3 末徆酸素各段における脱リグニン率

昇しており，ほぼ設胡通りと岇ている。なお酸素の分 配比率は 1 塔目で全体の 55〜60\%を添加し，アルカ リは全量 1 塔目で添加している。

末晒最終段のプレスは，国内では 1 号機となるフィ 一ド濃度が中濃度の DPB であるが, 脱水能力など性 能の面では低濃度夕イプの DPA と同等である。ただ し操業面ではDPBの方が濃度変動に対し若干シビア であり，インレット部のノズル詰りを起こすことがあ るため, 供給濃度は設計より低めで連転している。プ レスの採用によって洗浄水の使用量が低減出来るが,
表 4 漂白条件

\begin{tabular}{c|c|c|c|c}
\hline & D 0 段 & Eo 段 & Dn 段 & D 1 段 \\
\hline 温度 $(\%)$ & $10 \sim 11$ & $10 \sim 11$ & $10 \sim 11$ & $10 \sim 11$ \\
\hline 温度 $\left({ }^{\circ} \mathrm{C}\right)$ & $59 \sim 62$ & $56 \sim 61$ & $65 \sim 70$ & $64 \sim 70$ \\
\hline $\mathrm{pH}$ & $2.8 \sim 3.0$ & $9.0 \sim 10.5$ & $5.0 \sim 5.2$ & $4.5 \sim 5.0$ \\
\hline $\begin{array}{c}\text { 反応時間 } \\
(\min )\end{array}$ & 60 & 70 & 8 & 180 \\
\hline
\end{tabular}

注）生産 1,200 BKP·ADt/D 時

DPB は洗浄水が 2 段添加方式となっており，1段目 は土バコンデンセイト，2段目は高温水，と洗浄水を 使い分けることで更なる節水を実現している。COD キャリオーバーは, 高脱水なため, 測定法による違い もあるが 3.8 4. $8 \mathrm{Kg} \mathrm{ADtである。}$

\section{3 晒工程の操業状況}

漂白条件を表 4 に示す。

$\mathrm{E}$ 系における各漂白段での白色度と $\mathrm{K}$ 価の推移を 図 4 に示す。

当社では D 0 段での出口白色度 70〜71 をターゲッ トとしており，製品白色度は 85 で抄紙機へ供給して いる。一般にいわれている通り ECF 漂白での DEK 価は高く，D０段と同程度である。また塩素ガスを用 いた従来の漂白では, Eo 段での白色度がC D 段の白 色度より低下する傾向にあったが, ECF 漂白では, Eo 段白色度が D 0 段と同じか，数ポイント高い。

トータルの $\mathrm{ClO}_{2}$ 添加率に対する各段の割合を図 5 に示す。

スタートアップ当初は最終白色度が下がらないよう にD０段白色度を高めに操業していたが，D０段での 添加を強化しても, 白色度の上昇は頭打ちとなり, 結 果として白色度の割に添加だけが高めになってしまっ た。その後は眓 5 に示した様にD 0 段で 4〜 5 割, 残 りの 5〜6 割を $\mathrm{DnD}$ 段での添加としている。

\section{4 品質の状況}

表 5 に最終仕上りパルプ品質を示す。 $\mathrm{O}_{2}$ 段前の相 対粘度は 6 ヶ月平均で 10.5 であり，これは D系より 1.5 ポイント程高い。晒仕上り後ではその差が更に広 がり, 繊維を傷め難い ITC 蒸解と, 塩素とハイポを 使用しない ECF 漂白の効果といえる。

従来からの夾雑物の管理值は $5.0 \mathrm{~mm}^{2} 100 \mathrm{~g}$ 以下 であるが，E系はクリーナー入口でほぼ，そのレベル でありクリーナー出口では $0.9 \mathrm{~mm}^{2} 100 \mathrm{~g}$ とかなり 低くなった。またこの 1 年間の操業を通して,

・連釜の不調などでカッパー価が上昇しても夾雑物 


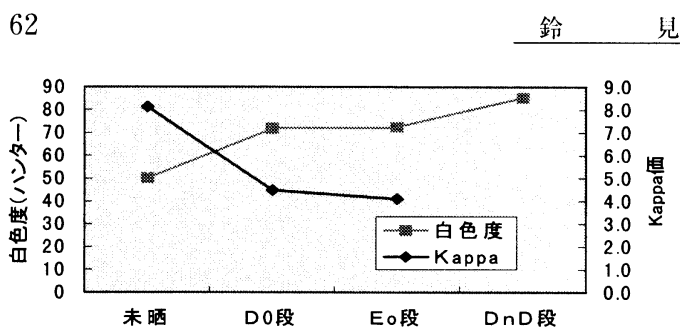

図 4 各段における白色度と Kappa 值

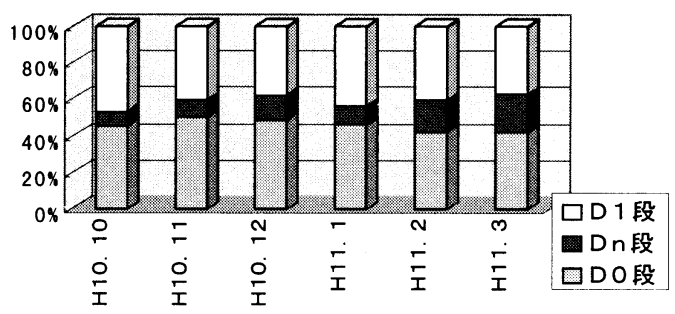

図 $5 \mathrm{ClO}_{2}$ トータル添加率に対する各段の割合

\section{が増加しない}

・薬液添加不足で仕上り白色度が低下しても夾雑物 が増加しない

などの特徴があり，これはダスト除去システムやスリ ットスクリーン, クリーナーが良好である他, ECF 漂白導入の大きなメリットである。また最終白色度の バラッキ, $\mathrm{PC}$ 価なども従来より向上しており，これ らは抄紙機へも好影響を与えている。

\section{4. 環境への影響}

$\mathrm{E}$ 系の設計当時, 米国のクラスタールールは未決で あり, 当社でも ECF か TCF かの議論となった。最 終的には

・オゾンを使用した場合の実操業と品質への影響

・古紙リサイクル性を高める為のパルプ強度の向上.

・諸外国の環境規制項目の中で日本に適用されてい ないクロロホルム等の動向

などを重要視し, 排水負荷低減に伴なう排水処理コス トの節減が, 漂白薬品コストアップ分をカバーできる 見通しがたったことで ECF の採用に決定した。AOX (吸着性有機ハロゲン化合物) やクロロホルム等の排 出量の実績は表 6 の通りである。

以前から環境問題に対し積極的に取り組んでいたこ とから, 従来法でも AOX は日本の自主規制值を大き く下回っていた。しかし ECF 漂白の導入によって更 に 10 分の 1 以下となり, 大気中へのクロロホルム発 生量も 100 分の 1 以下への減少となった。これは米国 のクラスタールールにも十分合致したプラントと自負 している。
表 5 パルプ品質

\begin{tabular}{|c|c|c|c|c|}
\hline \multicolumn{2}{|c|}{ 粘＼cjkstart度 } & \multicolumn{2}{|c|}{ 夾雑物 } & \multirow{2}{*}{$\begin{array}{c}\text { 褪色 } \\
\text { (PC 価) }\end{array}$} \\
\hline $\mathrm{O}_{2}$ 段前 & 仕上り & D 1 後 & 仕上り & \\
\hline 10.5 & 7.8 & 5.7 & 0.9 & 0.5 \\
\hline
\end{tabular}

注）夾雑物の単位は $\mathrm{mm}^{2} / 100 \mathrm{~g}$ 粘度：王研法 JIS 相対粘度

\section{5. 操 業 性}

\section{1 DCS オペレーション}

DCS は既設の, 横河電機センタム V との互換性か ら同社のセンタム CS を採用し，数ヶ月後には D 系列 も合わせてセンタム CSに更新した。これによってグ ラフィックやシーケンスの作成がかなり容易になり， オペレーターが自分達で新しいシーケンスを作成した り，使いやすい工夫を凝らしている。

1,200トン規模のプラントの運転停止はオペレータ 一にとってもかなりの夐担増になると尒想され， $\mathrm{E}$ 系 ファイバーラインのほとんどの部分に自動立上げ／立 下げシーケンスを用意した。しかし実際には自動シー ケンスを試す間も無く運転に入り、個別シーケンス以 外は現在も使用していない。立上げ／立下げは手動で も予想よりスムーズであり, DCS 上では数名で操作 している。ただし立上げの際，中濃度アップフローが 中心で中間夕ンクが少ない事から，工程の安定には多 少の時間が懸かっている。水運転からいかに早く中濃 度にもって行くかがポイントであり，更なる検討が必 要と考えている。

\subsection{0 段 K 価制御}

$\mathrm{E}$ 系における各種制御の中で特に目新しい物は無い が, ECF 漂白におけるファーストステージ D 0 段の 管理は，最終白色度の穴定化と薬品原単位の削減にお いて重要であり以下に紹介する。

当社では図 6 に亦した Kappa 価制御と日標白色度 制御の 2 通りの制御方法を用意した。

通常はKappa 価制御を使用しており，D０出口白 色度を直 1 回測定し, 結果によってオペレーターが D $\mathrm{K}$ の值を任意に与えている。操業が安定している時 は D K を調整する必要は無いが, 材種変更や立上げ 時など, $\mathrm{ClO}_{2}$ の添加が過剰過ぎると，逆にD 0 人口 の白色度指示が低下することがある。この様な時は才 ペレーターが濃度, 白色, 残塩などの操業因子から実 際に白色度が低下しているのかどうか判断し，D K を調整している。Kappa 価制御でも日標白色度によ る補正を掛けているが, 目標白色度の指示值は用意し 
表 6 環境への影響

\begin{tabular}{c|c|c|c|c|c}
\hline \multirow{2}{*}{} & \multicolumn{3}{|c|}{ 放流水 } & \multicolumn{2}{c}{ クロロホルム } \\
\cline { 2 - 6 } & $\begin{array}{c}\mathrm{AOX} \\
(\mathrm{kg} / \mathrm{ADt})\end{array}$ & $\begin{array}{c}\text { 色度 } \\
(\mathrm{ppm})\end{array}$ & $\begin{array}{c}\mathrm{BOD} \\
(\mathrm{ppm})\end{array}$ & $\begin{array}{c}\text { 大気 } \\
(\mathrm{g} / \mathrm{ADt})\end{array}$ & $\begin{array}{c}\text { 排水 } \\
(\mathrm{g} / \mathrm{ADt})\end{array}$ \\
\hline 従来法 & 0.56 & $100 \sim 150$ & 10 & 130 & 80 \\
\hline $\mathrm{ECF}$ & 0.05 & 70 & 5 & 0.6 & 0.3 \\
\hline
\end{tabular}

\section{- Kappa 価制御}

$\mathrm{ClO}_{2}$ 添加率=D K $\times(\mathrm{D} 0$ 入口 $\mathrm{Kappa}$ 価一目標出口 Kappa 価 $) \times \mathrm{F}$

$\mathrm{D}: \mathrm{K}$ : Kappa 価を1下げるのに必要な $\mathrm{ClO}_{2}$ 添加率

F ：目標白色度による補正

・補正白色度制御

$\mathrm{ClO}_{2}$ 添加率 $=$ 目標白色度の設定亡補正白色度の指示による PID 制御

目標白色度 : オペレーターが設定

補正白色度: 流量, 温度, 白色, 残塩, Kappa 価, pHから作られる白色度

図 6 D 0 段の $\mathrm{ClO}_{2}$ 添加率制御

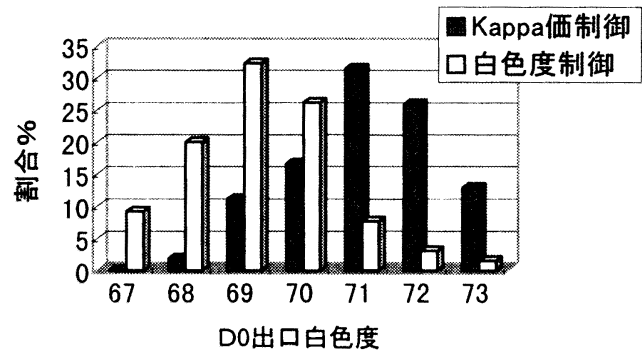

図 7 D 0 出口白色度の比較

たパラメーターの中で白色と残塩しか使っていないの が現状であり，非定常時にも対応させることが今後の 課題の 1 つである。

図7に2 ケ月間での Kappa 価制御と白色度制御で の Do 出口白色度の比較を示す。当社での D 0 出口白 色度の夕ーゲット 70〜 71 に対して, 白色度制御の時 は低目が多く，白色度 69 がピークとなっている。ま たバラッキ範囲も白色度制御の方が若干大きくなって いる。この傾向は最終白色度まで続き, 白色度制御で は夕ーゲットの 85 に対してやはり低目である（図 8)。 これらから僅かな差ではあるが，Kappa 価制御の方 がバラツキが少ないといえる。

\section{6. 今後の課題}

日本初の $\mathrm{ECF}$ 大型プラントとして稼動して 1 年以 上が経ち, 安定した品質と環境面での大きな効果を得

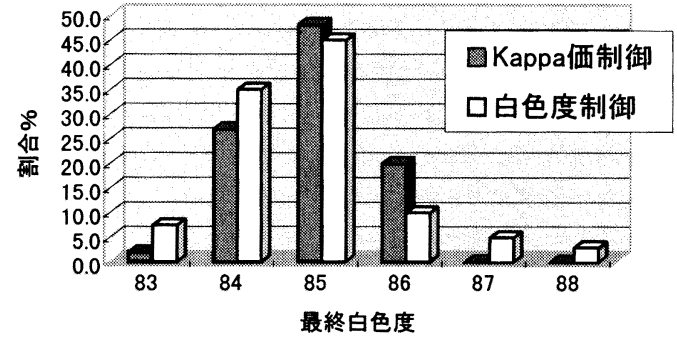

図 8 最終白色度の比較

ることができた。また通常操業時は蒸気使用がゼロで あり, エネルギー面でもロスが少なく, 当初の目標を 概ね達成することができた。しかし依然として ECF 漂白の未知なる部分が多いのも事実であり今後とも研 究, 検討を進め,

- ECF 最適漂白条件の確立

・更なる環境負荷の低減

・適切な設備診断によるトラブルの回避 に向けて努力して行く所存である。

\section{7. 謝辞}

過去 1 年間において種々のトラブルも経験してきた が, 現在の安定操業に至ることができたのはメーカー 各社のご協力の賜物であり, この場を借りて心から感 謝し，お礼申し上げます。 